Article

\title{
Relative and Absolute Stereochemistry of Diacarperoxides: Antimalarial Norditerpene Endoperoxides from Marine Sponge Diacarnus megaspinorhabdosa
}

\section{Fan Yang ${ }^{1, \dagger}$, Yike Zou ${ }^{2, \dagger}$, Ru-Ping Wang ${ }^{1,3, \dagger}$, Mark T. Hamann ${ }^{2}$, Hong-Jun Zhang ${ }^{4}$,} Wei-Hua Jiao ${ }^{1}$, Bing-Nan Han ${ }^{1}$, Shao-Jiang Song ${ }^{3, *}$ and Hou-Wen Lin ${ }^{1,5}, *$

1 Key Laboratory for Marine Drugs, Department of Pharmacy, Renji Hospital, Shanghai Jiao Tong University School of Medicine, Shanghai 200127, China; E-Mails: bil11985@126.com (F.Y.); wangruping_sy@163.com (R.-P.W.); jiaoweihua1982@sina.com (W.-H.J.); hanbingnan@shsmu.edu.cn (B.-N.H.)

2 Department of Pharmacognosy and National Center for Natural Products Research (NCNPR), School of Pharmacy, The University of Mississippi, Oxford, MS 38677, USA;

E-Mails: yzou@olemiss.edu (Y.Z.); mthamann@olemiss.edu (M.T.H.)

3 School of Traditional Chinese Materia Medica, Shenyang Pharmaceutical University, Shenyang 110016, China

4 Dujiangyan Center of Aeromedical Assessment and Training of Air Force, Dujiangyan 611830, China; E-Mail: chinabludo@126.com

5 Laboratory of Marine Drugs, Department of Pharmacy, Changzheng Hospital, Second Military Medical University, Shanghai 200003, China

$\dagger$ These authors contributed equally to this work.

* Authors to whom correspondence should be addressed;

E-Mails: songshaojiang@syphu.edu.cn (S.-J.S.); hwlin@sjtu.edu.cn (H.-W.L.); Tel./Fax: +86-24-2398-6510 (S.-J.S.); Tel./Fax: +86-21-6838-3346 (H.-W.L.).

Received: 16 June 2014; in revised form: 24 July 2014 / Accepted: 25 July 2014 / Published: 8 August 2014

\footnotetext{
Abstract: Five new norditerpene endoperoxides, named diacarperoxides $\mathrm{H}-\mathrm{L}$ (1-5), and a new norditerpene diol, called diacardiol B (6), were isolated from the South China Sea sponge, Diacarnus megaspinorhabdosa. Their structures, including conformations and absolute configurations, were determined by using spectroscopic analyses, computational approaches and chemical degradation. Diacarperoxides H-J (1-3) showed some interesting stereochemical issues, as well as antimalarial activity.
} 
Keywords: antimalarial; marine sponge; endoperoxide

\section{Introduction}

Malaria kills a child every minute, 154-289 million people are infected each year [1]. The plant-derived quinine family of antimalarials has provided centuries of relief for this disease. The long history of usage had, however, produced drug resistance, which was then relieved by incorporating the artemisinin class isolated from the plant Artemisia annua [2,3]. Exploring bioactive secondary metabolites from marine invertebrates has provided us potent leads fighting against this disease [4], the marine-derived endoperoxide family has been known for decades and has generated interest for drug discovery $[5,6]$. Computation is now seeing greater utility in the natural product field, including quantitative modeling on the molecular scale to disclose structural information, as well as in complex molecular systems to rationalize bioactivities targeting fatal diseases [7-9]. By using computational approaches, spectroscopic analyses and chemical degradation, we have assigned five new norditerpene endoperoxides, named diacarperoxides H-L (1-5), together with a new norditerpene diol, diacardiol B (6) from the marine sponge, Diacarnus megaspinorhabdosa (Figure 1). Herein, we report the details of the isolation and structural elucidation of these compounds.

Figure 1. Chemical structures of Compounds 1-6.

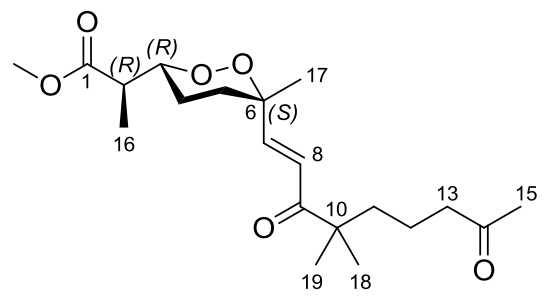

1

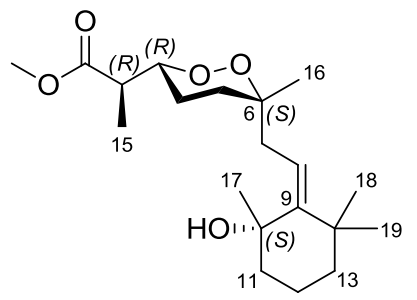

4

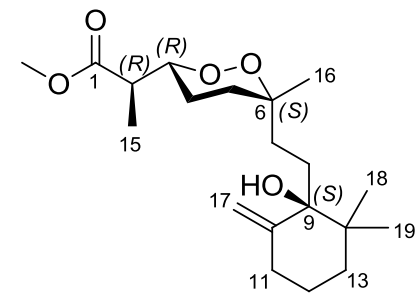

2

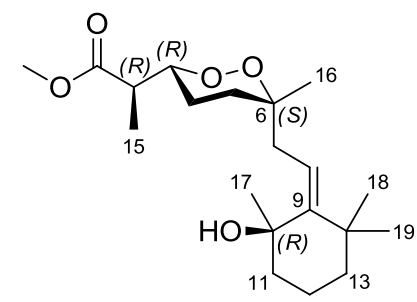

5

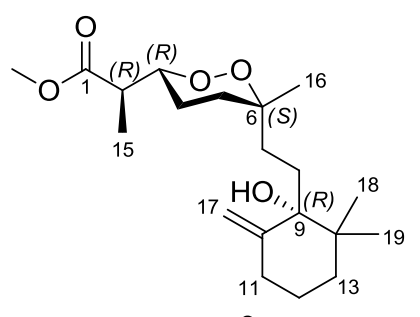

3

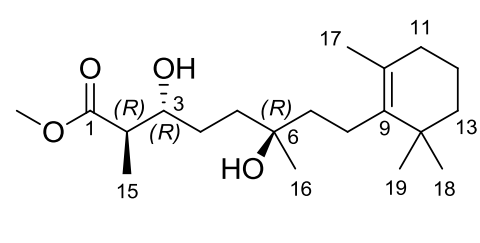

6

\section{Results and Discussion}

Five new norditerpene endoperoxides (1-5) were obtained from the $\mathrm{CH}_{2} \mathrm{Cl}_{2}$ extract of the sponge. The signal patterns for a 1,2-dioxane ring and a substituted methyl propionate group were acquired from NMR, establishing a scaffold of the marine-derived endoperoxide class [10,11]. Further analysis of the NMR spectra (Tables 1 and 2) provided evidence for the existence of monoterpene substitutions different from reported derivatives [12,13]. The stereochemical issues were encountered either because of conformational flexibility or two distal stereogenic centers (vide infra). Traditionally, the determination 
of the relative configurations of this type of compound counted on the chemical shift differences based on the empirical rule developed by Capon and Macleod [14], and the absolute configuration primarily relied on optical rotation [15] or conducting semisynthesis, since only three XRD (X-ray diffraction) structures in this class were reported $[6,16,17]$. In this work, the structures of the new norditerpene endoperoxides were determined by using spectroscopic analyses and computational approaches, including DFT (density functional theory)-based molecular modeling, conformational analysis and NMR and ECD (electronic circular dichroism) calculations.

Diacarperoxide $\mathrm{H}$ (1) was isolated as colorless oil. The molecular formula of $\mathrm{C}_{20} \mathrm{H}_{32} \mathrm{O}_{6}$ was determined by the analysis of HRESIMS (high resolution electrospray ionization mass spectroscopy) data with five degrees of unsaturation. The ${ }^{1} \mathrm{H}$ and ${ }^{13} \mathrm{C}$ NMR signal patterns suggested a norditerpene endoperoxide core and established an isolated spin system, allowing the assignment of C-1-C-6, C-16 and $\mathrm{C}-17$ positions $[18,19]$. Analyzing from the remaining signals in the low field region of ${ }^{13} \mathrm{C} \mathrm{NMR}$, another two carbonyl functional groups $\left(\delta_{\mathrm{C}} 208.5\right.$ and 203.8) and two olefinic carbons $\left(\delta_{\mathrm{C}} 147.6\right.$ and 124.3) were deduced. The $\mathrm{sp}^{2}$ carbons ( $\delta_{\mathrm{C}} 124.3$ and 147.6) were proven to be located at the $\alpha$ and $\beta$ positions of the carbonyl $\left(\delta_{\mathrm{C}} 203.8\right)$, based on the HMBC correlations from the corresponding olefinic protons $\mathrm{H}-7\left(\delta_{\mathrm{H}} 6.88\right)$ and $\mathrm{H}-8\left(\delta_{\mathrm{H}} 6.75\right)$ to the carbonyl C-9 $\left(\delta_{\mathrm{C}} 203.8\right)$ (Figure 2$)$. This olefinic functional group was attached to the quaternary C-6 $\left(\delta_{\mathrm{C}} 80.9\right)$ on the endoperoxide core, which was deduced from the HMBC correlations from $\mathrm{H}-7\left(\delta_{\mathrm{H}} 6.88\right)$ and $\mathrm{H}-8\left(\delta_{\mathrm{H}} 6.75\right)$ to $\mathrm{C}-6$, thus assigning the positions of $\mathrm{C}-7$ and $\mathrm{C}-8$, respectively. The large coupling constant of the two olefinic protons $(15.6 \mathrm{~Hz})$ and the NOESY correlation between $\mathrm{H}-8\left(\delta_{\mathrm{H}} 6.75\right)$ and 17-methyl protons $\left(\delta_{\mathrm{H}} 1.24\right)$ determined a trans double bond in an isolated spin system. Another quaternary carbon $\left(\mathrm{C}-10, \delta_{\mathrm{C}} 46.5\right)$ with geminal dimethyl groups was connected to the carbonyl C-9 according to the HMBC correlations from six overlapped methyl protons $\left(\delta_{\mathrm{H}} 1.14\right)$ to $\mathrm{C}-9$. The remaining one covalent connection of $\mathrm{C}-10$ elongated an unbranched alkyl chain through three consecutive methylene groups to a terminal acetyl functional group, establishing the last spin system, on the basis of COSY correlations of $11-\mathrm{CH}_{2}$ and $12-\mathrm{CH}_{2}$ $\left(\delta_{\mathrm{H}} 1.51\right)$ with $13-\mathrm{CH}_{2}\left(\delta_{\mathrm{H}} 2.41\right)$. The $\mathrm{HMBC}$ correlations from dimethyl protons $18-\mathrm{CH}_{3}$ and $19-\mathrm{CH}_{3}$ $\left(\delta_{\mathrm{H}} 1.14\right)$ to the methylene carbon $\mathrm{C}-11\left(\delta_{\mathrm{C}} 38.8\right)$ and from the methylene protons $13-\mathrm{CH}_{2}$ and methyl protons $15-\mathrm{CH}_{3}\left(\delta_{\mathrm{H}} 2.12\right)$ to the carbonyl C-14 $\left(\delta_{\mathrm{C}} 208.5\right)$, aligning the positions $\mathrm{C}-11-\mathrm{C}-15$. Attaching to the endoperoxide core, the acyclic side chain (C-7-C-15) was elucidated furnishing the gross structure of 1. The signal splitting pattern of $\mathrm{H}-3\left(\delta_{\mathrm{H}} 4.32, J=9.0,2.5 \mathrm{~Hz}\right)$ suggested anti and gauche relationships between $\mathrm{H}-3-\mathrm{H}-4_{\mathrm{ax}}$ and $\mathrm{H}-3-\mathrm{H}-4_{\mathrm{eq}}$, respectively. According to the Karplus equation [20], H-3 was therefore in the axial position representing major conformations. These spatial relationships were then confirmed by the strong NOESY correlations of $\mathrm{H}-3\left(\delta_{\mathrm{H}} 4.32\right) / \mathrm{H}-4 \mathrm{~b}\left(\delta_{\mathrm{H}} 1.68\right)$ and $\mathrm{H}-5 \mathrm{a}\left(\delta_{\mathrm{H}} 1.83\right)$. On the other side, the olefinic C-7 was in the axial position based on the NOESY correlation between $\mathrm{H}-7\left(\delta_{\mathrm{H}}\right.$ 6.88) and $\mathrm{H}-5 \mathrm{~b}\left(\delta_{\mathrm{H}} 2.03\right), \mathrm{H}-5 \mathrm{a}\left(\delta_{\mathrm{H}} 1.83\right)$ and Me-17 $\left(\delta_{\mathrm{H}} 1.24\right), \mathrm{H}-5 \mathrm{~b}$ and $\mathrm{H}-8\left(\delta_{\mathrm{H}} 6.75\right), \mathrm{H}-4 \mathrm{a}\left(\delta_{\mathrm{H}} 1.51\right)$ and H-8 (Figure 3). Calculations were then conducted to confirm this conformation. Resulting from conformational analyses and DFT calculations, an averaged $A$-value of $1.8 \mathrm{kcal} / \mathrm{mol}$ was attributed to 1 from our model study (Figure 4) [21]. 
Table 1. ${ }^{1} \mathrm{H}$ NMR data of Compounds $\mathbf{1}-\mathbf{6}$ in $\mathrm{CDCl}_{3}(500 \mathrm{MHz})$.

\begin{tabular}{|c|c|c|c|c|c|c|}
\hline Position & $1, \delta_{\mathrm{H}}$, mult. $(J$ in $\mathrm{Hz})$ & $2, \delta_{\mathrm{H}}$, mult. $(J$ in $\mathrm{Hz})$ & $3, \delta_{\mathrm{H}}$, mult. $(J$ in $\mathrm{Hz})$ & $4, \delta_{\mathrm{H}}$, mult. $(J$ in $\mathrm{Hz})$ & $5, \delta_{\mathrm{H}}$, mult. $(J$ in $\mathrm{Hz})$ & $6, \delta_{\mathrm{H}}$, mult. $(J$ in $\mathrm{Hz})$ \\
\hline 2 & $2.41, \mathrm{t}(7.2)$ & 2.54, quin $(6.5)$ & 2.60, quin $(7.5)$ & 2.59, quin $(7.5)$ & 2.65, quin $(7.5)$ & 2.56, quin $(7.0)$ \\
\hline 3 & $4.32, \operatorname{td}(9.0,2.5)$ & $4.23, \operatorname{td}(9.0,2.5)$ & $4.24, \operatorname{td}(9.0,1.5)$ & 4.23, ddd $(8.0,6.5,2.0)$ & 4.23, ddd $(8.0,6.5,1.5)$ & $3.70, \mathrm{~m}$ \\
\hline 4 & $\begin{array}{l}\mathrm{H}_{4 \mathrm{a}(\mathrm{ax})}, 1.51, \mathrm{~m} \\
\mathrm{H}_{4 \mathrm{~b}(\mathrm{eq})}, 1.68, \mathrm{~m}\end{array}$ & $1.67, \mathrm{~m}$ & $1.64, \mathrm{~m}$ & $1.72, \mathrm{~m}$ & $1.72, \mathrm{~m}$ & $\begin{array}{l}\mathrm{H}_{4 a}, 1.56, \mathrm{~m} \\
\mathrm{H}_{4 \mathrm{~b}}, 1.69, \mathrm{~m}\end{array}$ \\
\hline 5 & $\begin{array}{l}\mathrm{H}_{5 \mathrm{a}(\mathrm{ax})}, 1.83, \mathrm{td}(13.2,4.5) \\
\mathrm{H}_{5 \mathrm{~b}(\mathrm{eq})}, 2.03, \mathrm{dt}(13.5,3.6)\end{array}$ & $1.67, \mathrm{~m}$ & $1.64, \mathrm{~m}$ & $\begin{array}{l}\mathrm{H}_{5 \mathrm{a}(\mathrm{ax})}, 1.72, \mathrm{~m} \\
\mathrm{H}_{5 \mathrm{~b}(\mathrm{eq})}, 1.83, \mathrm{~m}\end{array}$ & $\begin{array}{l}1.72, \mathrm{~m} \\
1.83, \mathrm{~m}\end{array}$ & $\begin{array}{l}\mathrm{H}_{5 \mathrm{a}}, 1.59, \mathrm{~m} \\
\mathrm{H}_{5 \mathrm{~b}}, 1.69, \mathrm{~m} \\
\end{array}$ \\
\hline 7 & $6.88, \mathrm{~d}(15.6)$ & $\begin{array}{l}\mathrm{H}_{7 \mathrm{a}}, 1.30, \mathrm{td}(8.0,4.5) \\
\mathrm{H}_{7 \mathrm{~b}}, 1.67, \mathrm{~m}\end{array}$ & $\begin{array}{l}\mathrm{H}_{7 \mathrm{a}}, 1.18, \mathrm{~m} \\
\mathrm{H}_{7 \mathrm{~b}}, 1.90, \mathrm{~m}\end{array}$ & $\begin{array}{l}\mathrm{H}_{7 \mathrm{a}}, 2.42, \mathrm{dd}(15.5,8.0) \\
\mathrm{H}_{7 \mathrm{~b}}, 3.36, \mathrm{dd}(16.0,7.0)\end{array}$ & $\begin{array}{l}\mathrm{H}_{7 \mathrm{a}}, 2.83, \mathrm{dd}(15.5,7.0) \\
\mathrm{H}_{7 \mathrm{~b}}, 2.97, \mathrm{dd}(15.0,7.5)\end{array}$ & $1.56, \mathrm{~m}$ \\
\hline 8 & $6.75, \mathrm{~d}(15.6)$ & $\begin{array}{l}\mathrm{H}_{8 \mathrm{a}}, 1.51, \mathrm{~m} \\
\mathrm{H}_{8 \mathrm{~b}}, 1.87, \mathrm{td}(13.0,3.0)\end{array}$ & $\begin{array}{l}\mathrm{H}_{8 \mathrm{a}}, 1.64, \mathrm{~m} \\
\mathrm{H}_{8 \mathrm{~b}}, 1.90, \mathrm{~m} \\
\end{array}$ & $5.54, \mathrm{t}(7.5)$ & $5.59, \mathrm{t}(7.5)$ & $2.03, \mathrm{dd}(11.0,5.0)$ \\
\hline 11 & $1.51, \mathrm{~m}$ & $\begin{array}{l}\mathrm{H}_{11 \mathrm{a}(\mathrm{ax})}, 2.11, \mathrm{td}(13.0,3.0) \\
\mathrm{H}_{11 \mathrm{~b}(\mathrm{eq})}, 2.27, \text { br.d }(13.0)\end{array}$ & $\begin{array}{l}\mathrm{H}_{11 \mathrm{a}(\mathrm{ax})}, 1.77, \operatorname{td}(13.5,5.5) \\
\mathrm{H}_{11 \mathrm{~b}(\mathrm{eq})}, 2.30, \text { br.d }(13.5)\end{array}$ & $\begin{array}{l}\mathrm{H}_{11 \mathrm{a}(\mathrm{ax})}, 1.56, \mathrm{~m} \\
\mathrm{H}_{11 \mathrm{~b}(\mathrm{eq})}, 1.91, \mathrm{~m} \\
\end{array}$ & $\begin{array}{l}\mathrm{H}_{11 \mathrm{a}(\mathrm{ax})}, 1.56, \mathrm{~m} \\
\mathrm{H}_{11 \mathrm{~b}(\mathrm{eq})}, 1.83, \mathrm{~m} \\
\end{array}$ & $1.90, \mathrm{t}(6.0)$ \\
\hline 12 & $1.51, \mathrm{~m}$ & $1.51, \mathrm{~m}$ & $1.64, \mathrm{~m}$ & $1.56, \mathrm{~m}$ & $1.56, \mathrm{~m}$ & $\begin{array}{l}\mathrm{H}_{12 \mathrm{a}}, 1.41, \mathrm{~m} \\
\mathrm{H}_{12 \mathrm{~b}}, 1.56, \mathrm{~m}\end{array}$ \\
\hline 13 & $2.41, \mathrm{t}(7.2)$ & $\begin{array}{l}\mathrm{H}_{13 \mathrm{a}(\mathrm{ax})}, 1.36, \mathrm{~m} \\
\mathrm{H}_{13 \mathrm{~b}(\mathrm{eq})}, 1.67, \mathrm{~m}\end{array}$ & $\begin{array}{l}\mathrm{H}_{13 \mathrm{a}(\mathrm{ax})}, 1.38, \text { br.d }(13.0) \\
\mathrm{H}_{13 \mathrm{~b}(\mathrm{eq})}, 1.64, \mathrm{~m}\end{array}$ & $1.41, \mathrm{~m}$ & $1.41, \mathrm{~m}$ & $1.41, \mathrm{~m}$ \\
\hline 15 & $2.12, \mathrm{~s}$ & $1.12, \mathrm{~d}(7.0)$ & $1.14, \mathrm{~d}(7.0)$ & $1.12, \mathrm{~d}(7.0)$ & $1.14, \mathrm{~d}(7.0)$ & $1.21, \mathrm{~d}(7.2)$ \\
\hline 16 & $1.10, \mathrm{~d}(7.2)$ & $1.09, \mathrm{~s}$ & $1.09, \mathrm{~s}$ & $1.13, \mathrm{~s}$ & $1.13, \mathrm{~s}$ & $1.21, \mathrm{~s}$ \\
\hline 17 & $1.24, \mathrm{~s}$ & $\begin{array}{l}\mathrm{H}_{17 \mathrm{a}}, 4.81 \text {, br.s } \\
\mathrm{H}_{17 \mathrm{~b}}, 4.89 \text {, br.s }\end{array}$ & $\begin{array}{l}\mathrm{H}_{17 \mathrm{a}}, 4.89 \text {, br.s } \\
\mathrm{H}_{17 \mathrm{~b}}, 4.91 \text {, br.s }\end{array}$ & $1.42, \mathrm{~s}$ & $1.41, \mathrm{~s}$ & $1.59, \mathrm{~s}$ \\
\hline 18 & $1.14, \mathrm{~s}$ & $0.97, \mathrm{~s}$ & $0.98, \mathrm{~s}$ & $1.18, \mathrm{~s}$ & $1.17, \mathrm{~s}$ & $0.99, \mathrm{~s}$ \\
\hline 19 & $1.14, \mathrm{~s}$ & $0.89, \mathrm{~s}$ & $0.91, \mathrm{~s}$ & $1.07, \mathrm{~s}$ & $1.08, \mathrm{~s}$ & $0.99, \mathrm{~s}$ \\
\hline $1-\mathrm{OCH}_{3}$ & $3.70, \mathrm{~s}$ & $3.69, \mathrm{~s}$ & $3.70, \mathrm{~s}$ & $3.70, \mathrm{~s}$ & $3.70, \mathrm{~s}$ & $3.71, \mathrm{~s}$ \\
\hline
\end{tabular}


Table 2. ${ }^{13} \mathrm{C}$ NMR data and DEPT analysis of Compounds $\mathbf{1}-\mathbf{6}$ in $\mathrm{CDCl}_{3}(125 \mathrm{MHz})$.

\begin{tabular}{|c|c|c|c|c|c|c|}
\hline Position & $1, \delta_{\mathrm{C}}$, DEPT & $2, \delta_{\mathrm{C}}$, DEPT & $3, \delta_{C}$, DEPT & $4, \delta_{\mathrm{C}}$, DEPT & $5, \delta_{\mathrm{C}}$, DEPT & $6, \delta_{\mathrm{C}}$, DEPT \\
\hline 1 & $174.1, \mathrm{C}$ & $174.3, \mathrm{C}$ & $174.3, \mathrm{C}$ & 174.6, C & 174.6, C & $176.4, \mathrm{C}$ \\
\hline 2 & $42.5, \mathrm{CH}$ & $42.6, \mathrm{CH}$ & $42.5, \mathrm{CH}$ & $42.5, \mathrm{CH}$ & $42.5, \mathrm{CH}$ & $45.4, \mathrm{CH}$ \\
\hline 3 & $81.6, \mathrm{CH}$ & $81.0, \mathrm{CH}$ & $81.2, \mathrm{CH}$ & $81.6, \mathrm{CH}$ & $81.4, \mathrm{CH}$ & $73.7, \mathrm{CH}$ \\
\hline 4 & $23.5, \mathrm{CH}_{2}$ & $22.4, \mathrm{CH}_{2}$ & $22.4, \mathrm{CH}_{2}$ & $22.7, \mathrm{CH}_{2}$ & $22.5, \mathrm{CH}_{2}$ & $28.8, \mathrm{CH}_{2}$ \\
\hline 5 & $33.5, \mathrm{CH}_{2}$ & $33.3, \mathrm{CH}_{2}$ & $32.9, \mathrm{CH}_{2}$ & $32.3, \mathrm{CH}_{2}$ & $32.4, \mathrm{CH}_{2}$ & $37.3, \mathrm{CH}_{2}$ \\
\hline 6 & $80.9, \mathrm{C}$ & $79.9, \mathrm{C}$ & $79.9, \mathrm{C}$ & $80.2, \mathrm{C}$ & $80.4, \mathrm{C}$ & $72.7, \mathrm{C}$ \\
\hline 7 & 147.6, CH & 28.3, $\mathrm{CH}_{2}$ & $28.4, \mathrm{CH}_{2}$ & $37.5, \mathrm{CH}_{2}$ & $37.5, \mathrm{CH}_{2}$ & $42.2, \mathrm{CH}_{2}$ \\
\hline 8 & 124.3, CH & 25.6, $\mathrm{CH}_{2}$ & 26.1, $\mathrm{CH}_{2}$ & $120.1, \mathrm{CH}$ & $120.6, \mathrm{CH}$ & $22.8, \mathrm{CH}_{2}$ \\
\hline 9 & $203.8, \mathrm{C}$ & $80.0, \mathrm{C}$ & $79.6, \mathrm{C}$ & 152.6, C & 151.6, C & 136.7, C \\
\hline 10 & $46.5, \mathrm{C}$ & $151.3, \mathrm{C}$ & $150.3, \mathrm{C}$ & 73.9, C & $74.0, \mathrm{C}$ & 127.0, C \\
\hline 11 & $38.8, \mathrm{CH}_{2}$ & $33.8, \mathrm{CH}_{2}$ & $34.0, \mathrm{CH}_{2}$ & $44.2, \mathrm{CH}_{2}$ & $43.9, \mathrm{CH}_{2}$ & $32.8, \mathrm{CH}_{2}$ \\
\hline 12 & $19.0, \mathrm{CH}_{2}$ & $22.8, \mathrm{CH}_{2}$ & $22.8, \mathrm{CH}_{2}$ & $19.4, \mathrm{CH}_{2}$ & $19.3, \mathrm{CH}_{2}$ & $19.5, \mathrm{CH}_{2}$ \\
\hline 13 & $43.9, \mathrm{CH}_{2}$ & $38.0, \mathrm{CH}_{2}$ & $38.1, \mathrm{CH}_{2}$ & $39.9, \mathrm{CH}_{2}$ & $39.9, \mathrm{CH}_{2}$ & $39.9, \mathrm{CH}_{2}$ \\
\hline 14 & $208.5, \mathrm{C}$ & $39.9, \mathrm{C}$ & $39.8, \mathrm{C}$ & $37.5, \mathrm{C}$ & $37.5, \mathrm{C}$ & $35.1, \mathrm{C}$ \\
\hline 15 & $29.8, \mathrm{CH}_{3}$ & $12.5, \mathrm{CH}_{3}$ & $12.8, \mathrm{CH}_{3}$ & $13.0, \mathrm{CH}_{3}$ & $13.0, \mathrm{CH}_{3}$ & $14.2, \mathrm{CH}_{3}$ \\
\hline 16 & 12.6, $\mathrm{CH}_{3}$ & $23.9, \mathrm{CH}_{3}$ & $23.9, \mathrm{CH}_{3}$ & $23.8, \mathrm{CH}_{3}$ & $24.2, \mathrm{CH}_{3}$ & 26.6, $\mathrm{CH}_{3}$ \\
\hline 17 & 26.1, $\mathrm{CH}_{3}$ & 107.9, $\mathrm{CH}_{2}$ & 108.6, $\mathrm{CH}_{2}$ & $29.2, \mathrm{CH}_{3}$ & 29.4, $\mathrm{CH}_{3}$ & $19.8, \mathrm{CH}_{3}$ \\
\hline 18 & 24.1, $\mathrm{CH}_{3}$ & $24.1, \mathrm{CH}_{3}$ & $24.2, \mathrm{CH}_{3}$ & $32.3, \mathrm{CH}_{3}$ & $32.4, \mathrm{CH}_{3}$ & $28.7, \mathrm{CH}_{3}$ \\
\hline 19 & $23.9, \mathrm{CH}_{3}$ & $22.2, \mathrm{CH}_{3}$ & $22.4, \mathrm{CH}_{3}$ & $32.0, \mathrm{CH}_{3}$ & $32.0, \mathrm{CH}_{3}$ & $28.7, \mathrm{CH}_{3}$ \\
\hline 20 & $51.9, \mathrm{OCH}_{3}$ & $51.8, \mathrm{OCH}_{3}$ & $51.9, \mathrm{OCH}_{3}$ & $51.9, \mathrm{OCH}_{3}$ & $51.9, \mathrm{OCH}_{3}$ & $51.7, \mathrm{OCH}_{3}$ \\
\hline
\end{tabular}


Figure 2. Key HMBC correlations for Compound 1.

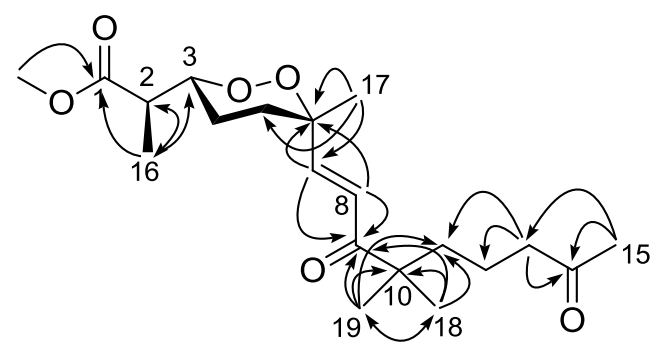

1

Figure 3. Key NOESY correlations for Compound 1.

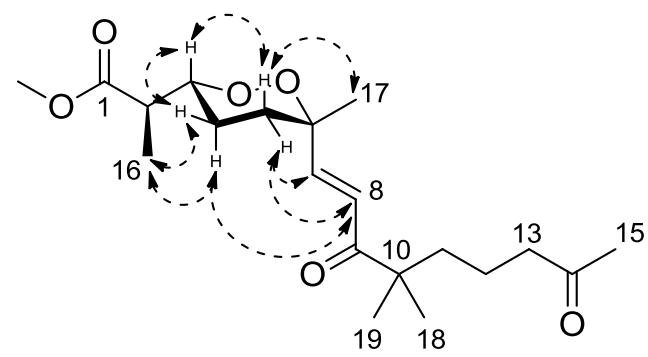

Figure 4. $A$-value determination of the endoperoxide core.
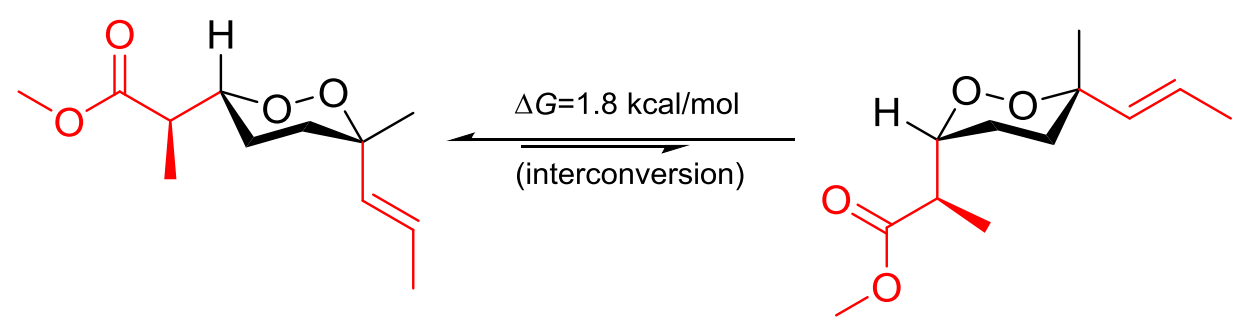

From the assigned conformation, the relative configuration of C-2/C-3 was then suggested as erythro ( $2 R, 3 R$ or $2 S, 3 S)$ by the empirical method, which was based on the ${ }^{1} \mathrm{H}$ NMR chemical shift difference of the methyl group C-16 between the erythro and threo configuration [14]. To backup this method, NMR calculations were performed at different theoretical levels [22]. The calculated chemical shift for H-16 $\left(\delta_{\text {calc. }} 1.08 / \delta_{\text {exp. }} 1.10\right)$ at the B3LYP/6-31G(d,p) level matched precisely with our experimental value; while for the supposed threo configuration $(2 R, 3 S$ or $2 S, 3 R)$, the calculated value for $\mathrm{H}-16$ $\left(\delta_{\text {calc. epimer }} 1.31 / \delta_{\text {exp. }} 1.24-1.26\right)$ showed further downfield from Capon's report [14]. These results confirmed the erythro configuration of C-2 with C-3 and secured Capon's method. Not being mentioned by the report, probably because of the trivial differences, C-16 chemical shifts for those threo configurations were slightly upfield compared with the erythro ones. DFT calculations were able to track this trend and resolve the small differences, although the relative chemical shifts for ${ }^{13} \mathrm{C}$ NMR could not be predicted as accurately as for the proton NMR, resulting in C-16 $\left(\delta_{\mathrm{C}} 12.4-12.8 / \delta_{\text {calc. }}\right.$. 15.7-16.1 for erythro, and $\delta_{\mathrm{C}} 13.2-13.5 / \delta_{\text {calc. }} 17.0-18.1$ for threo) [14]. NMR calculations for $2-5$ (vide infra) were also conducted and matched well with the experiments (Table 3). The chemical shift differences between the two possible diastereomers revealed that $\mathrm{C}-16$ was anti to the peroxide group in the erythro configuration, whereas it was gauche in the threo configuration representing the major 
conformations. These preferred arrangements were due to minimizing the unfavored gauche interactions (Figure 5). Calculations for the minor conformations of erythro/gauche and threo/anti showed mismatching (Table 3).

Table 3. Calculated NMR chemical shifts for the predominant conformations of Compounds 1-5 using different methods applying the PCM (polarizable continuum model) solvation model.

\begin{tabular}{|c|c|c|c|c|c|c|}
\hline \multirow{2}{*}{ Species } & B3LYP & MPW1PW91 & \multirow{2}{*}{ Experimental } & B3LYP & MPW1PW91 & \multirow{2}{*}{ Experimental } \\
\hline & (erythro/threo) & (erythro/threo) & & (erythro/threo) & (erythro/threo) & \\
\hline 1 & $\delta_{\mathrm{H} 16} 1.08 / 1.31$ & $\delta_{\mathrm{H} 16} 1.01 / 1.25$ & $\delta_{\mathrm{H} 16} 1.10$ & $\delta_{\mathrm{C} 16} 15.8 / 17.5$ & $\delta_{\mathrm{C} 16} 15.0 / 16.7$ & $\delta_{\mathrm{C} 16} 12.6$ \\
\hline 2 & $\delta_{\mathrm{H} 15} 1.11 / 1.29$ & $\delta_{\mathrm{H} 15} 1.03 / 1.24$ & $\delta_{\mathrm{H} 15} 1.09$ & $\delta_{\mathrm{C} 15} 16.1 / 17.0$ & $\delta_{\mathrm{C} 15} 15.0 / 16.2$ & $\delta_{\mathrm{C} 15} 12.5$ \\
\hline 3 & $\delta_{\mathrm{H} 15} 1.13 / 1.35$ & $\delta_{\mathrm{H} 15} 1.06 / 1.29$ & $\delta_{\mathrm{H} 15} 1.09$ & $\delta_{\mathrm{C} 15} 15.9 / 17.9$ & $\delta_{\mathrm{C} 15} 15.0 / 17.0$ & $\delta_{\mathrm{C} 15} 12.8$ \\
\hline 4 & $\delta_{\mathrm{H} 15} 1.11 / 1.34$ & $\delta_{\mathrm{H} 15} 1.04 / 1.26$ & $\delta_{\mathrm{H} 15} 1.13$ & $\delta_{\mathrm{C} 15} 15.7 / 17.9$ & $\delta_{\mathrm{C} 15} 15.0 / 16.6$ & $\delta_{\mathrm{C} 15} 13.0$ \\
\hline 5 & $\delta_{\mathrm{H} 15} 1.12 / 1.36$ & $\delta_{\mathrm{H} 15} 1.05 / 1.30$ & $\delta_{\mathrm{H} 15} 1.13$ & $\delta_{\mathrm{C} 15} 16.1 / 18.1$ & $\delta_{\mathrm{C} 15} 15.3 / 17.2$ & $\delta_{\mathrm{C} 15} 13.0$ \\
\hline
\end{tabular}

Calculated chemical shifts (in ppm) of C-16 and H-16 for 1, and C-15 and H-15 of the same position for 2-5, basis set of $6-31 G(d, p)$.

Figure 5. Conformational analysis of C-2-C-3 using Newman projection (blue and green numeric numbers indicating calculated and experimental values, respectively; curved red arrows indicating gauche interactions).
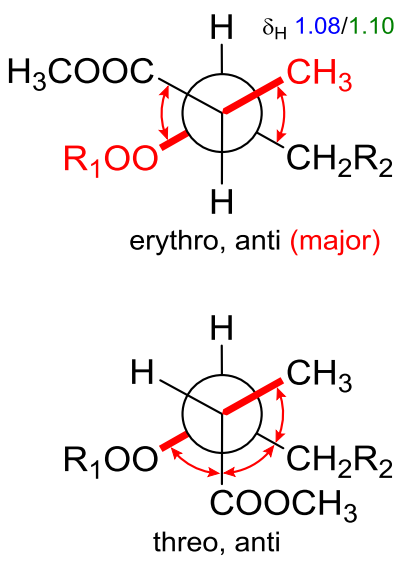
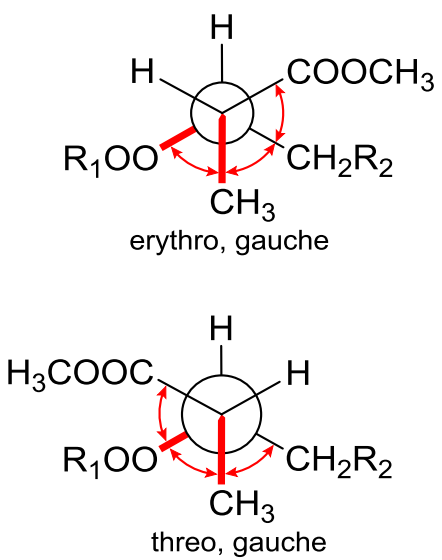
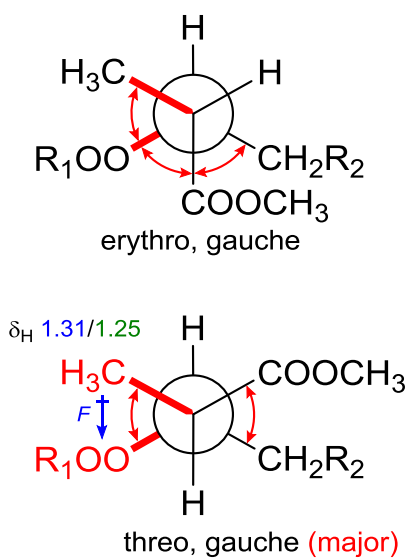

On the grounds of these results, we believed that it is the field effect produced by the peroxide moiety withdrawing electrons from the methyl C-16 in the threo configuration, thus deshield it to low field, whereas C-16 in the erythro configuration is distal from the peroxy; thus, no deshielding was observed (Figure 5). Although no XRD structure of 1 could be obtained, our calculations showed the same conformation (Figure S52 in Supplementary Information) of the endoperoxide core as all of the three closely-related crystal structures [12-14]. Back to our calculations, it is the configurationally dependent conformations that thus dictate the chemical shift differences and underlie the empirical rule.

With the relative configuration and major conformations of 1 established, ECD computation was used for determining the absolute configuration. Time-dependent density function theory (TDDFT) was applied for the excited-state calculations, and the experimental ECD spectrum was used for comparison. The exciton from $\pi \rightarrow \pi^{*}$ transition of the $\alpha, \beta$-unsaturated carbonyl producing the CE (Cotton effect) 
around $240 \mathrm{~nm}$ was able to be reproduced in silico. From the overlaid spectra (Figure 6), the absolute configuration of 1 was thus elucidated as $2 R, 3 R, 6 S$.

Figure 6. Boltzmann averaged ECD of diacarperoxide H (1).

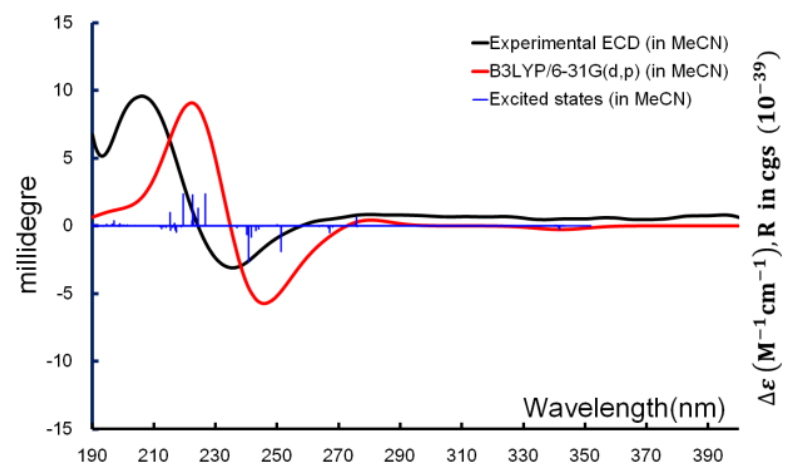

Diacarperoxide I (2) was obtained as a colorless oil with a molecular formula of $\mathrm{C}_{20} \mathrm{H}_{34} \mathrm{O}_{5}$ deduced from the HRESIMS data, implying four degrees of unsaturation. Three degrees were assigned to a carbonyl group $\left(\delta_{\mathrm{C}} 174.3\right)$, a pair of olefinic carbons $\left(\delta_{\mathrm{C}} 151.3,107.9\right)$ and a typical endoperoxide ring characterized by two carbons $\left(\delta_{\mathrm{C}} 81.0 / \delta_{\mathrm{H}} 4.23, \delta_{\mathrm{C}} 79.9\right)$, while the remaining one degree of unsaturation suggested an additional ring closure. It was demonstrated containing the endoperoxide core as in 1 by comparing their 1D and 2D NMR data. The attachment on C-6 was, however, significantly different from 1 ; instead of an olefinic substitution, a group of two consecutive methylene was attached to C-6, supported by the HMBC correlations of $\mathrm{H}-16\left(\delta_{\mathrm{H}} 1.09\right) / \mathrm{C}-7\left(\delta_{\mathrm{C}} 28.3\right)$ and $\mathrm{H}-7$ $\left(\delta_{\mathrm{H}} 1.30\right) / \mathrm{C}-16\left(\delta_{\mathrm{C}} 23.9\right)$, in addition to the COSY correlations of $\mathrm{H}-7 \mathrm{a}\left(\delta_{\mathrm{H}} 1.30\right)$ with $\mathrm{CH}_{2}-8\left(\delta_{\mathrm{H}} 1.51\right.$, $1.87)$, together assigning the methylene $\mathrm{C}-7\left(\delta_{\mathrm{C}} 28.3\right)$ and $\mathrm{C}-8\left(\delta_{\mathrm{C}} 25.6\right)$. Another three methylenes, a dimethylated quaternary carbon, a disubstituted olefinic carbon and an oxyl quaternary carbon lynchpin tethered a six-membered ring. This arrangement was elucidated starting from the strong HMBC cross-peaks from two methyl protons $18-\mathrm{CH}_{3}\left(\delta_{\mathrm{H}} 0.97, \mathrm{~s}\right)$ and $19-\mathrm{CH}_{3}\left(\delta_{\mathrm{H}} 0.89\right.$, s) to the quaternary $\mathrm{C}-14\left(\delta_{\mathrm{C}} 39.9\right)$ to the methyl carbon of each other and to the quaternary carbon C-9 $\left(\delta_{\mathrm{C}} 80.0\right)$; and then, verified by the HMBC correlations from the axial $\mathrm{H}-13 \mathrm{a}\left(\delta_{\mathrm{H}} 1.36\right)$ to the geminal dimethyl $\mathrm{C}-18\left(\delta_{\mathrm{C}} 24.1\right)$ and $\mathrm{C}-19\left(\delta_{\mathrm{C}} 22.2\right)$ and from the terminal olefinic $\mathrm{CH}_{2}-17\left(\delta_{\mathrm{H}} 4.81,4.89\right)$ to C-9 $\left(\delta_{\mathrm{H}} 80.0\right)$ and C-11 $\left(\delta_{\mathrm{H}} 33.8\right)$; and finally, confirmed by the COSY correlation of a well resolved proton resonance $\mathrm{H}-11 \mathrm{~b}\left(\delta_{\mathrm{H}} 2.27\right)$ with $\mathrm{CH}_{2}-12\left(\delta_{\mathrm{H}} 1.51\right)$, fixing the positions of C-9-C-19. This enclosure together with $\mathrm{C}-8$ formed a monoterpene motif attaching to the endoperoxide core.

Relative configurations for the three stereogenic centers in the endoperoxide core were determined using the same method as for $\mathbf{1}$, but the existence of an additional center, C-9, with a tertiary hydroxyl group attachment challenged us in two different manners. First, the configuration of C-9 was difficult to be spatially related to the other three centers because of the remote distance. Second, it was difficult to handle with the limited amount of our sample by applying degradation or modification on this chemical environment. It was fortunate that a closely related compound, diacarperoxide $\mathrm{J}(\mathbf{3})$, was purified in our hands with the gross structure elucidated by comparing the spectroscopic data with $\mathbf{2}$. Notably, all of the ${ }^{1} \mathrm{H}$ and ${ }^{13} \mathrm{C}$ NMR chemical shifts of $\mathbf{3}$ were almost identical to 2, except for the nuclei surround C-9 (Tables 1 and 2), which suggested a different relative configuration, but we still cannot conclude that 3 was the C-9 epimer of $\mathbf{2}$, since the opposite stereogenicity of each center on the marine-derived 
endoperoxide class has been reported before [6,23,24]. Theoretically, there were four possibilities regarding the absolute configurations, e.g., for the diastereomeric-pair Compounds $\mathbf{2}$ and 3. However, based on the fact that Compounds $\mathbf{2}$ and $\mathbf{3}$ were diastereomers other than enantiomers, there were only two possible combinations, which were $2 R, 3 R, 6 S, 9 S / 2 R, 3 R, 6 S, 9 R$ and $2 S, 3 S, 6 R, 9 R / 2 S, 3 S, 6 R, 9 S$, and the Compounds $\mathbf{2}$ and $\mathbf{3}$ have to be one of those combinations. Anisotropic CEs (200 nm, positive; $210 \mathrm{~nm}$, negative) of $\mathbf{2}$ and $\mathbf{3}$ were recorded by the ECD experiments, which prompted us to use exited-state calculations investigating the absolute configurations directly before establishing the relative configurations. A combination of four possible absolute configurations of $\mathbf{2}$ and $\mathbf{3}$ were modeled, and the subsequential excited-state calculations reproduced the Cotton effect, therefore assigning the absolute configurations of $\mathbf{2}$ and $\mathbf{3}$ as $2 R, 3 R, 6 S, 9 S$ and $2 R, 3 R, 6 S, 9 R$, respectively (Figure 7).

Figure 7. Boltzmann averaged ECD of diacarperoxides I and $\mathrm{J}(\mathbf{2}$ and $\mathbf{3})$.

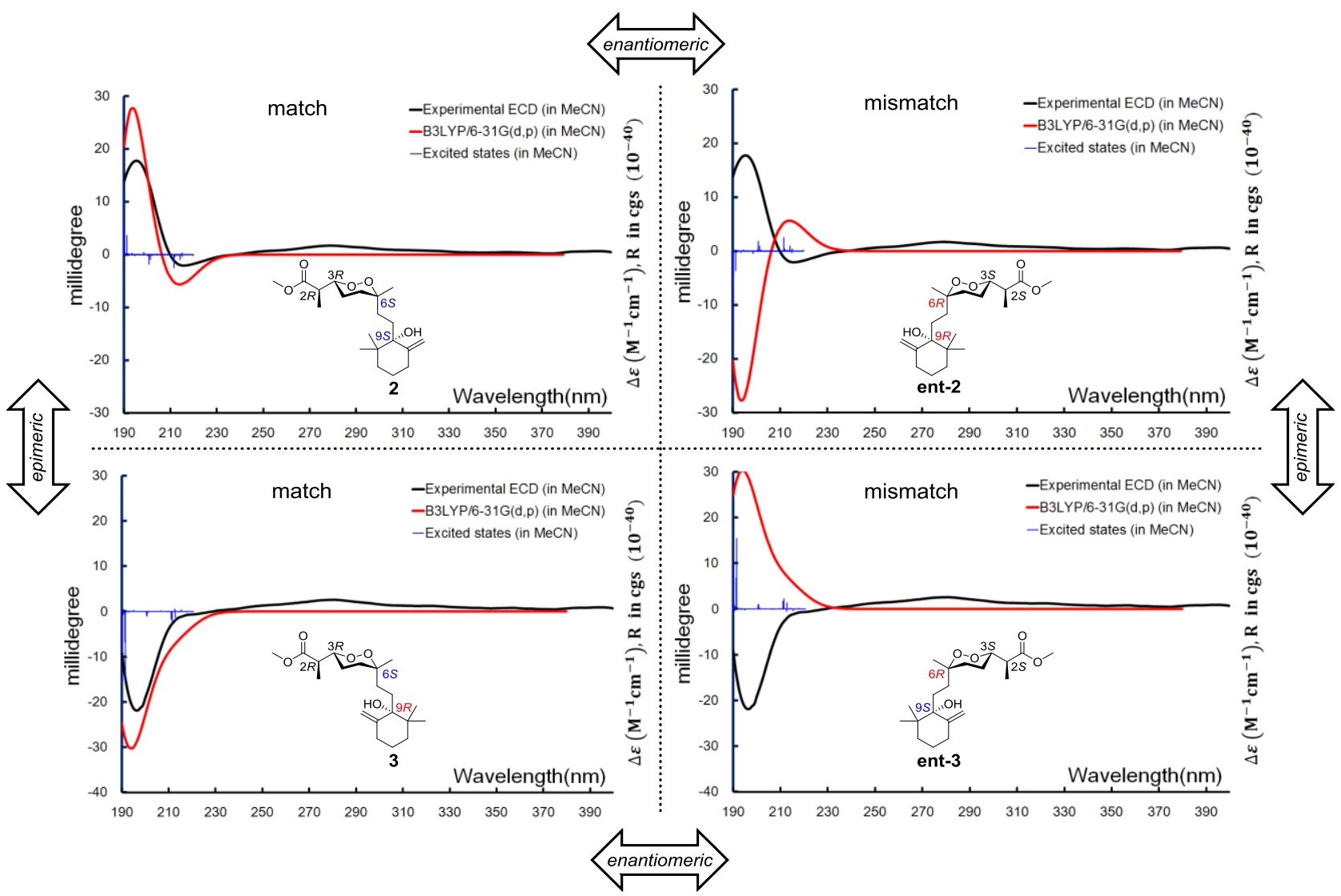

Diacarperoxide K (4) was determined as a structural isomer of $\mathbf{2}$ and $\mathbf{3}$ by comparing the spectroscopic data. The differences were an extra methyl group showing $3 \mathrm{H}\left(\delta_{\mathrm{H}} 1.42\right.$, s) and $\mathrm{C}\left(\delta_{\mathrm{C}} 29.2\right)$, and a monosubstituted olefinic carbon showing C-8 $\left(\delta_{\mathrm{C}} 120.1\right)$ and $\mathrm{H}-8\left(\delta_{\mathrm{H}} 5.54, \mathrm{t}, J=7.5 \mathrm{~Hz}\right)$; in addition to the absence of $\mathrm{C}-8$ methylene resonance together postulated an $\mathrm{E} 1$ on the tertiary hydroxyl group and a hydrolysis of the olefinic functional group of 2 or $\mathbf{3}$. By analyzing the NMR spectra, the position of a trisubstituted olefin, assigned as $\mathrm{C}-8$ and $\mathrm{C}-9$, could be fixed from the $\mathrm{COSY}$ correlations of $\mathrm{CH}_{2}-7$ $\left(\delta_{\mathrm{H}} 2.42,3.36\right)$ with $\mathrm{H}-8\left(\delta_{\mathrm{H}} 5.54\right)$. The extra tertiary methyl group showed HMBC correlations from $17-\mathrm{CH}_{3}\left(\delta_{\mathrm{H}} 1.42\right)$ to $\mathrm{C}-11\left(\delta_{\mathrm{C}} 44.2\right), \mathrm{C}-10\left(\delta_{\mathrm{C}} 73.9\right)$ and $\mathrm{C}-9\left(\delta_{\mathrm{C}} 152.6\right)$, determining its position as $\mathrm{C}-17$ attached to the oxyl quaternary carbon $\mathrm{C}-10\left(\delta_{\mathrm{C}} 73.9\right)$, which was vicinal to the disubstituted $\mathrm{sp}^{2} \mathrm{C}-9$ $\left(\delta_{\mathrm{C}}\right.$ 152.6). The $Z$ configuration of the double bond was determined by the NOESY correlations between 
geminal dimethyl $\mathrm{H}-18\left(\delta_{\mathrm{H}} 1.18\right)$ and $\mathrm{H}-19\left(\delta_{\mathrm{H}} 1.07\right)$ and the olefinic proton $\mathrm{H}-8$. The remaining gross structure of 4 was unchanged from 2 and 3 by comparing the 1D and 2D NMR spectra. The same case as $\mathbf{2}$ and $\mathbf{3}$, for the diastereomeric-pair Compounds $\mathbf{4}$ and $\mathbf{5}$, there were only two possible combinations, which were $2 R, 3 R, 6 S, 10 S / 2 R, 3 R, 6 S, 10 R$ and $2 S, 3 S, 6 R, 10 R / 2 S, 3 S, 6 R, 10 S$. The similar stereochemistry issue of C-10 was solved by comparing with the ECD spectrum of isolated epimer diacarperoxide L (5). Acquiring from the major conformations (Figure S52 in Supplementary Information) and the diaxial NOESY correlations of $\mathbf{4}$ and $\mathbf{5}$, hydroxyl groups were in the equatorial positions, whereas the two methyl groups were surprisingly in the axil positions, producing inevitable 1,3-diaxial interactions, but compromising with higher $A$-values and avoiding more unfavored 1,3-allylic strains (Figure 8). Comparing the computed ECD with the experiments, the absolute configurations of $\mathbf{4}$ and $\mathbf{5}$ were thus assigned as $2 R, 3 R, 6 S, 10 S$ and $2 R, 3 R, 6 S, 10 R$, respectively (Figure 9).

Figure 8. Model study of the 1,3-diaxial interaction vs. 1,3-allylic strain of Compounds 4 and $\mathbf{5}$ applying the solvation model.
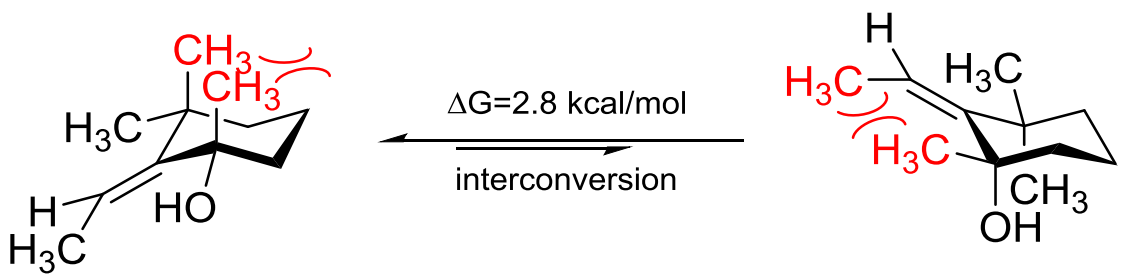

Figure 9. Boltzmann averaged ECD of diacarperoxides K and L (4 and 5).

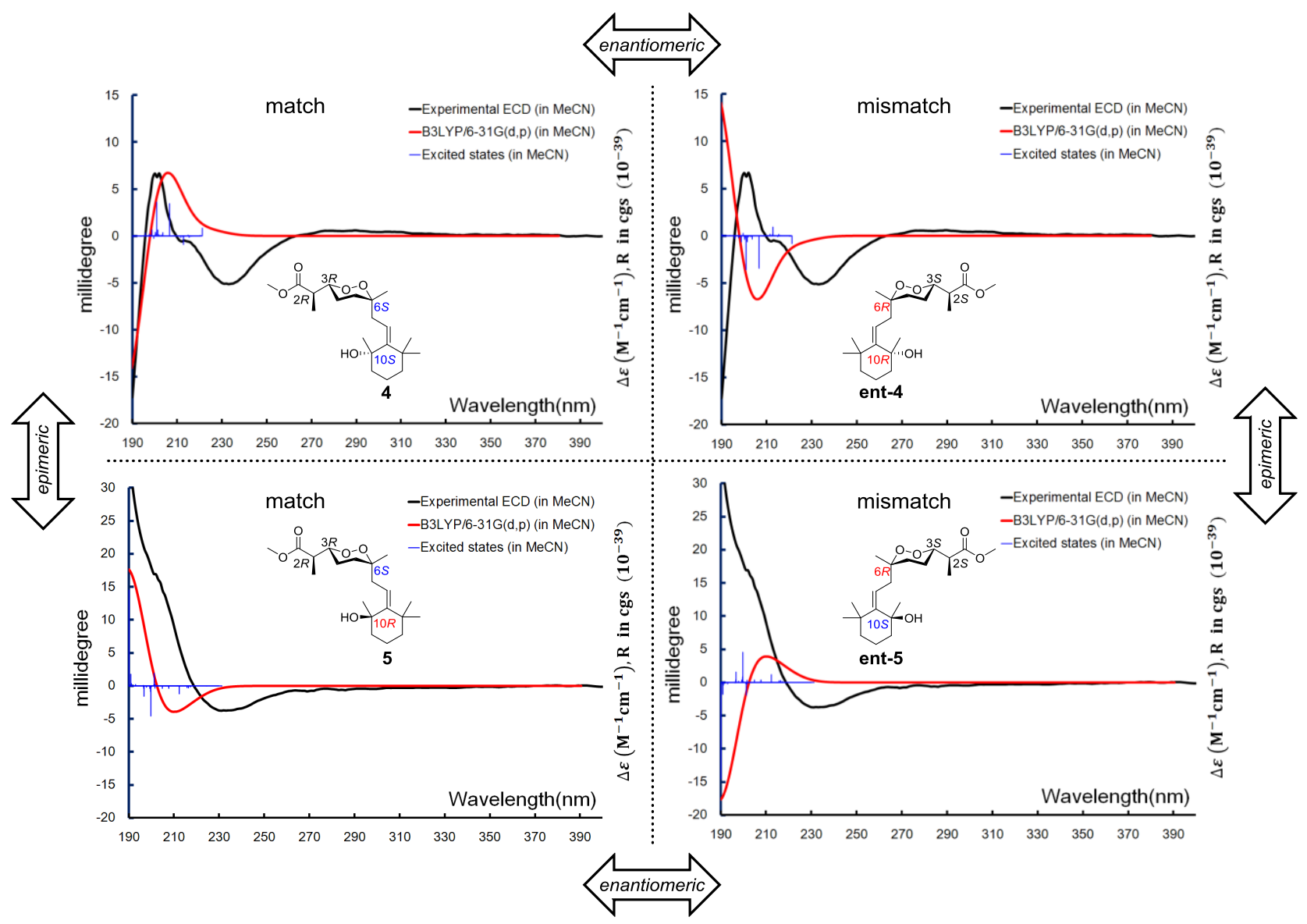


Diacardiol B (6) was obtained as a white solid. The HRESIMS data suggested a molecular formula of $\mathrm{C}_{20} \mathrm{H}_{36} \mathrm{O}_{4}$ with three degrees of unsaturation. Comparing the NMR spectra with $\mathbf{1}-\mathbf{5}$, the carbon chemical shifts presumably belonging to the endoperoxide core changed significantly, in which C-3 and C-6 were upfield from 81 and 80 ppm to 73.7 and 72.7 ppm, but C-4 and C-5 were downfield from 22 and 33 ppm to 28.8 and $37.3 \mathrm{ppm}$, respectively. Compound $\mathbf{6}$ was likely generated from homolysis of the peroxy. The cyclic monoterpene part was also changed for the absence of the quaternary oxyl carbon resonance and the emergence of a tetrasubstituted olefinic $C-9\left(\delta_{C} 136.7\right)$ and $C-10\left(\delta_{C} 127.0\right)$. The olefin was at the C-9-C-10 position, determined by the $\mathrm{HMBC}$ correlations from four allylic methylene protons $8-\mathrm{CH}_{2}$ $\left(\delta_{\mathrm{H}} 2.03\right), 11-\mathrm{CH}_{2}\left(\delta_{\mathrm{H}} 1.90\right)$ and from the vinylic methyl protons $17-\mathrm{CH}_{3}\left(\delta_{\mathrm{H}} 1.59\right)$ to the olefinic carbons. Compound $\mathbf{6}$ was likely the acyclic form of nuapapuin A methyl ester. We applied chemical degradation on nuapapuin A methyl ester (which was also obtained by us from the same sponge) under reductive condition (Figure 10), and the product showed identical ${ }^{1} \mathrm{H}$ NMR spectrum and similar optical rotation with $\mathbf{6}$, verifying the structures of both of these two natural products [12,25]. To establish the absolute configuration of 6, modified Mosher's method [26,27] was applied, and NMR anisotropic analysis of corresponding product was used to assign the absolute configuration of 6 as $2 R, 3 R, 6 R$ (Figure 11).

Figure 10. Reductive cleavage of the peroxide in nuapapuin A methyl ester.
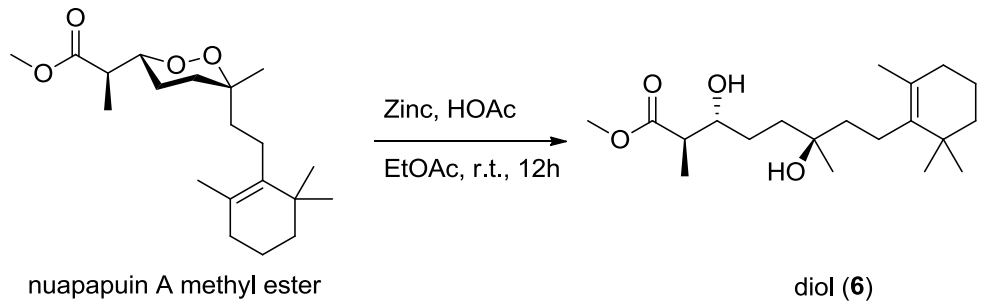

Figure 11. Determining the absolute configuration of diacardiol B (6) using the NMR anisotropy method.

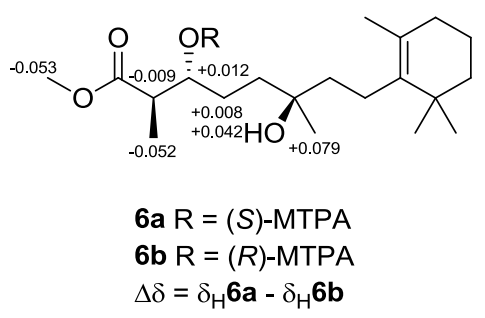

Diacarperoxides H-J (1-3) showed antimalarial activity against Plasmodium falciparum (W2 clones) in vitro with $\mathrm{IC}_{50}$ values of $12.9,4.8$ and $1.8 \mu \mathrm{M}$, while 2 and 3 exhibited antimalarial activity in vitro against $P$. falciparum (D6 clones) with $\mathrm{IC}_{50}$ values of 7.9 and $1.6 \mu \mathrm{M}$, respectively (Table 4); the $\mathrm{IC}_{50}$ values of the control drug artemisinin were 0.071 (D6 clones) and $0.14 \mu \mathrm{M}$ (W2 clones). The cytotoxicity against human cancer cell lines HeLa (cervical cancer), QGY-7703 (hepatocarcinoma), MDA-MB-231 (breast adenocarcinoma) and A549 (lung carcinoma) were tested for 1-6 (Tables S17-S20 in Supplementary Information); none of them showed significant cytotoxicity $\left(\mathrm{IC}_{50}>40 \mu \mathrm{M}\right)$. Interestingly, there is no significant difference between Compounds $\mathbf{2}$ and $\mathbf{3}$ in sensitivity to the two Plasmodium strains above, while Compound $\mathbf{1}$ is sensitive to the W2 clone strain; 
this may result from the acyclic side chain (C-7-C-15). Although the security index is relatively small, this type of marine endoperoxides could still be considered as potential drug candidates acting against malaria, and structure-activity relationships (SAR) and biological studies should be encouraged to be conducted in the future.

Table 4. In vitro antimalarial activity of Compounds $\mathbf{1}-\mathbf{3}$.

\begin{tabular}{|c|c|c|c|c|}
\hline \multirow{3}{*}{ Compound } & \multicolumn{4}{|c|}{ Plasmodium falciparum } \\
\hline & \multicolumn{2}{|c|}{ W2 Clone } & \multicolumn{2}{|c|}{ D6 Clone } \\
\hline & $\mathrm{IC}_{50}(\boldsymbol{\mu M})$ & SI $^{\mathrm{a}}$ & $\mathrm{IC}_{50}(\mu \mathrm{M})$ & SI \\
\hline 1 & 12.9 & 1.0 & not active & \\
\hline 2 & 4.8 & 2.8 & 7.9 & 1.7 \\
\hline 3 & 1.8 & 7.4 & 1.6 & 8.2 \\
\hline
\end{tabular}

\section{Experimental Section}

\subsection{General Experimental Procedures}

NMR experiments were performed on a $500 \mathrm{MHz}$ instrument (Bruker Biospin Corp., Billerica, MA, USA). High-resolution mass spectroscopic data were acquired using a TOFESIMS (Waters Corp., Milford, MA, USA). ECD spectra were recorded on a CD spectropolarimeter (Jasco Inc., Tokyo, Japan) with the path length of $1 \mathrm{~cm}$ and a scan width of 190 to $400 \mathrm{~nm}$, and optical rotation data were measured on a general polarimeter (Perkin-Elmer Inc., Waltham, MA, USA) with a sodium lamp. Reversed-phase HPLC was performed on a $\mathrm{C}_{18}$ column $(250 \times 10 \mathrm{~mm}, 5 \mu \mathrm{m})$ using a preparative HPLC instrument (Waters Corp., Milford, MA, USA) with a UV detector (Waters Corp., Milford, MA, USA). Column chromatography (CC) was performed on Sephadex LH-20 (Pharmacia Fine Chemicals, Piscataway, NJ, USA) and ODS-A (50 $\mu \mathrm{m}$, YMC Co. Ltd., Kyoto, Japan) columns, and vacuum liquid chromatography (VLC) was conducted on a column packed with silica gel (200-300 mesh, Qingdao Ocean Chemical Co., Jinan, China).

\subsection{Animal Material}

The Diacarnus megaspinorhabdosa sample was collected from Woody Island in the South China Sea during April, 2010, and identified by Prof. Jin-He Li (Institute of Oceanology, Chinese Academy of Sciences, Qingdao, China). A voucher sample (No. XD-2010008) was deposited in the Laboratory of Marine Drugs, Department of Pharmacy, Changzheng Hospital, Second Military Medical University, China.

\subsection{Extraction and Isolation}

The sponge ( $2 \mathrm{~kg}$, dry weight) was cut and extracted with 95\% aqueous EtOH. The crude extraction was concentrated in vacuo, yielding a brown gum, which was then suspended in $\mathrm{H}_{2} \mathrm{O}$ and participated with EtOAc and $n$-BuOH to afford EtOAc and $n$-BuOH extracts, respectively. The EtOAc extract was dissolved in $\mathrm{MeOH} / \mathrm{H}_{2} \mathrm{O}(9: 1, \mathrm{v} / \mathrm{v})$ extracted with petroleum ether to yield a brownish-red oil (30 g). The 
aqueous $\mathrm{MeOH}$ phase was then diluted to $\mathrm{MeOH} / \mathrm{H}_{2} \mathrm{O}(3: 2, \mathrm{v} / \mathrm{v})$ and extracted with $\mathrm{CH}_{2} \mathrm{Cl}_{2}$ to afford a crude extract (18 g), which was then subjected to VLC packed with silica gel gradiently eluted with an $n$-hexane/acetone system to yield eight fractions (Fr. A-H). Fraction C (4.9 g) was further separated on a reversed-phase $\mathrm{C}_{18}$ silica gel column to obtain four subfractions (Fr. C1-C4), and subfraction $\mathrm{C} 2$ $\left(210 \mathrm{mg}\right.$ ) was purified by HPLC (YMC-Pack Pro $\mathrm{C}_{18} R S, 5 \mu \mathrm{m}, 250 \times 10 \mathrm{~mm}, 1.5 \mathrm{~mL} / \mathrm{min}$, UV detection at 210 and $202 \mathrm{~nm}$ ) eluting with $\mathrm{CH}_{3} \mathrm{OH} / \mathrm{H}_{2} \mathrm{O}(75: 25)$ to yield $2(16 \mathrm{mg})$ and 3 (20 mg). Similarly, subfraction $\mathrm{C} 3(150 \mathrm{mg})$ was purified by $\mathrm{HPLC}$ eluted with $\mathrm{CH}_{3} \mathrm{OH} / \mathrm{H}_{2} \mathrm{O}(70: 30)$ to yield $4(10 \mathrm{mg})$ and 5 (7 mg). Fraction D (5.2 g) was purified by silica gel column eluted with $\mathrm{CH}_{2} \mathrm{Cl}_{2} / \mathrm{EtOAc}(8: 1$ to $1: 1, \mathrm{v} / \mathrm{v})$ to yield six subfractions (Fr. D1-D6), and subfraction D2 (100 mg) was isolated using a Sephadex LH-20 column eluted with $\mathrm{CH}_{2} \mathrm{Cl}_{2} / \mathrm{MeOH}(1: 1, \mathrm{v} / \mathrm{v})$ and then purified by HPLC to obtain 1 (30 mg). Fraction E (450 mg) was separated by silica gel column chromatography eluted with $\mathrm{CH}_{2} \mathrm{Cl}_{2} / \mathrm{EtOAc}$ $(7: 1-1: 1, v / v)$ to afford $6(18 \mathrm{mg})$.

Diacarperoxide H (1): colorless oil; $[\alpha]^{20}{ }_{\mathrm{D}}+52.7\left(c 0.28, \mathrm{CHCl}_{3}\right) ; \mathrm{CD}\left(\mathrm{CH}_{3} \mathrm{CN}, c 2.2 \times 10^{-4}\right) \lambda_{\max }$ (millidegree), $192(5.34) \mathrm{nm}, 204(9.43) \mathrm{nm}, 234(-3.05) \mathrm{nm} ; \mathrm{UV}\left(\mathrm{CH}_{3} \mathrm{CN}\right), \lambda_{\max }(\log \varepsilon): 196(2.66)$, $224(3.25) \mathrm{nm}$; IR (KBr) v $v_{\max }$ : 3463, 2953, 1740, 1715, 1693, 1627, 1459, 1364, 1266, 1200, 1167, 1078, 1009, 982, 950, 860, 738, $477 \mathrm{~cm}^{-1} ;{ }^{1} \mathrm{H} \mathrm{NMR}\left(\mathrm{CDCl}_{3}, 500 \mathrm{MHz}\right)$ and ${ }^{13} \mathrm{C} \mathrm{NMR}\left(\mathrm{CDCl}_{3}, 125 \mathrm{MHz}\right)$ data, see Tables 1 and 2; HRESIMS $m / z 391.2092$ (calcd. for $\mathrm{C}_{20} \mathrm{H}_{32} \mathrm{O}_{6} \mathrm{Na}, 391.2091$ ).

Diacarperoxide I (2): colorless oil; $[\alpha]^{20}{ }_{\mathrm{D}}+36.5\left(c 0.28, \mathrm{CHCl}_{3}\right) ; \mathrm{CD}\left(\mathrm{CH}_{3} \mathrm{CN}, c 2.2 \times 10^{-4}\right) \lambda_{\max }$ (millidegree), 195 (17.75) nm, 215 (-2.07) nm; UV $\left(\mathrm{CH}_{3} \mathrm{CN}\right), \lambda_{\max }(\log \varepsilon): 196$ (3.23), 246 (sh, 1.16) nm; IR (KBr) $v_{\max }$ : 3552, 2934, 2864, 1740, 1456, 1337, 1261, 1200, 1160, 1060, 1013, 898, 872, 802, 692, 621, $472 \mathrm{~cm}^{-1}$; ${ }^{1} \mathrm{H}$ NMR $\left(\mathrm{CDCl}_{3}, 500 \mathrm{MHz}\right)$ and ${ }^{13} \mathrm{C} \mathrm{NMR}\left(\mathrm{CDCl}_{3}, 125 \mathrm{MHz}\right)$ data, see Tables 1 and 2; HRESIMS $m / z 377.2296$ (calcd. for $\mathrm{C}_{20} \mathrm{H}_{34} \mathrm{O}_{5} \mathrm{Na}, 377.2299$ ).

Diacarperoxide J (3): colorless oil; $[\alpha]^{20}{ }_{\mathrm{D}}+59.1\left(c 0.64, \mathrm{CHCl}_{3}\right) ; \mathrm{CD}\left(\mathrm{CH}_{3} \mathrm{CN}, c 2.2 \times 10^{-4}\right) \lambda_{\max }$ (millidegree), 196 (-21.89) nm; UV $\left(\mathrm{CH}_{3} \mathrm{CN}\right), \lambda_{\max }(\log \varepsilon): 204$ (3.64) nm; IR (KBr) v $v_{\max }: 3557,2974$, 2938, 2865, 1740, 1457, 1378, 1267, 1201, 1162, 1061, 1014, $901 \mathrm{~cm}^{-1} ;{ }^{1} \mathrm{H}$ NMR $\left(\mathrm{CDCl}_{3}\right.$, $500 \mathrm{MHz})$ and ${ }^{13} \mathrm{C} \mathrm{NMR}\left(\mathrm{CDCl}_{3}, 125 \mathrm{MHz}\right)$ data, see Tables 1 and 2; HRESIMS $\mathrm{m} / \mathrm{z} 377.2301$ (calcd. for $\left.\mathrm{C}_{20} \mathrm{H}_{34} \mathrm{O}_{5} \mathrm{Na}, 377.2299\right)$.

Diacarperoxide K (4): colorless oil; $[\alpha]^{20}{ }_{\mathrm{D}}+41.0\left(c 0.20, \mathrm{CHCl}_{3}\right) ; \mathrm{CD}\left(\mathrm{CH}_{3} \mathrm{CN}, c 2.2 \times 10^{-4}\right) \lambda_{\max }$ (millidegree), $200(6.65) \mathrm{nm}, 232(-5.08) \mathrm{nm}$; UV ( $\left.\mathrm{CH}_{3} \mathrm{CN}\right), \lambda_{\max }(\log \varepsilon)$ : 196 (3.23), 222 (sh, 2.72) nm; IR (KBr) $v_{\max }: 3458,2930,2873,1740,1458,1374,1265,1199,1164,1074,1012,872 \mathrm{~cm}^{-1}$; ${ }^{1} \mathrm{H} \mathrm{NMR}\left(\mathrm{CDCl}_{3}, 500 \mathrm{MHz}\right)$ and ${ }^{13} \mathrm{C} \mathrm{NMR}\left(\mathrm{CDCl}_{3}, 125 \mathrm{MHz}\right)$ data, see Tables 1 and 2; HRESIMS $\mathrm{m} / \mathrm{z}$ 377.2297 (calcd. for $\mathrm{C}_{20} \mathrm{H}_{34} \mathrm{O}_{5} \mathrm{Na}, 377.2299$ ).

Diacarperoxide L (5): colorless oil; $[\alpha]^{20}{ }_{\mathrm{D}}+23.6\left(c 0.38, \mathrm{CHCl}_{3}\right) ; \mathrm{CD}\left(\mathrm{CH}_{3} \mathrm{CN}, c 2.2 \times 10^{-4}\right) \lambda_{\max }$ (millidegree), $230(-3.73) \mathrm{nm}$; UV $\left(\mathrm{CH}_{3} \mathrm{CN}\right), \lambda_{\max }(\log \varepsilon)$ : $198(3.25), 222$ (sh, 2.64) nm; IR (KBr) $v_{\max }$ : 3396, 2944, 2877, 1739, 1455, 1376, 1264, 1199, 1164, 1058, 1009, $904 \mathrm{~cm}^{-1} ;{ }^{1} \mathrm{H} \mathrm{NMR}\left(\mathrm{CDCl}_{3}\right.$, $500 \mathrm{MHz})$ and ${ }^{13} \mathrm{C} \mathrm{NMR}\left(\mathrm{CDCl}_{3}, 125 \mathrm{MHz}\right.$ ) data, see Tables 1 and 2; HRESIMS $\mathrm{m} / \mathrm{z} 377.2301$ (calcd. for $\mathrm{C}_{20} \mathrm{H}_{34} \mathrm{O}_{5} \mathrm{Na}, 377.2299$ ).

Diacardiol B (6): colorless oil; $[\alpha]^{20}{ }_{\mathrm{D}}-2.4\left(c\right.$ 0.50, $\left.\mathrm{CHCl}_{3}\right) ; \mathrm{UV}\left(\mathrm{CH}_{3} \mathrm{CN}\right), \lambda_{\max }(\log \varepsilon): 210(3.73) \mathrm{nm}$; IR (KBr) $v_{\max }: 3319,3208,2949,2927,2870,1740,1465,1435,1358,1199,1167,1123,1087,1043$, 
1025, 983, 968, 908, 886, 853, $754 \mathrm{~cm}^{-1} ;{ }^{1} \mathrm{H} \mathrm{NMR}\left(\mathrm{CDCl}_{3}, 500 \mathrm{MHz}\right)$ and ${ }^{13} \mathrm{C} \mathrm{NMR}\left(\mathrm{CDCl}_{3}, 125 \mathrm{MHz}\right)$ data, see Tables 1 and 2; HRESIMS $m / z 363.2506$ (calcd. for $\mathrm{C}_{20} \mathrm{H}_{36} \mathrm{O}_{4} \mathrm{Na}, 363.25058$ ).

Nuapapuin A methyl ester: Colorless oil; $[\alpha]^{20}{ }_{\mathrm{D}}+71.2\left(c\right.$ 0.67, $\left.\mathrm{CHCl}_{3}\right) ;{ }^{1} \mathrm{H} \mathrm{NMR}\left(\mathrm{CDCl}_{3}, 500 \mathrm{MHz}\right)$ : $\delta 2.58(1 \mathrm{H}, \mathrm{q}, J=7.5 \mathrm{~Hz}, \mathrm{H}-2), 4.27(1 \mathrm{H}, \mathrm{td}, J=8.5,3.0 \mathrm{~Hz}, \mathrm{H}-3), 1.17$ (3H, d, $J=7.5 \mathrm{~Hz}, 2-\mathrm{Me}), 1.16$ (3H, s, 6-Me), $3.70\left(3 \mathrm{H}, \mathrm{OCH}_{3}\right) ;{ }^{13} \mathrm{C} \mathrm{NMR}\left(\mathrm{CDCl}_{3}, 125 \mathrm{MHz}\right): \delta 174.3(\mathrm{C}-1), 42.5(\mathrm{C}-2), 81.0(\mathrm{C}-3)$, 32.8 (C-4), 35.1 (C-5), 80.2 (C-6), 22.5 (C-7), 22.2 (C-8), 136.7 (C-9), 127.1 (C-10), 32.7 (C-11), 19.6 (C-12), 39.9 (C-13), 34.8 (C-14), 12.4 (C-15), 23.6 (C-16), 19.7 (C-17), 28.5 (C-18), 28.7 (C-19), $51.9\left(\mathrm{OCH}_{3}\right)$.

\subsection{Reductive Cleavage of Nuapapuin A Methyl Ester}

A mixture of nuapapuin A methyl ester $(30 \mathrm{mg}, 88.6 \mu \mathrm{mol}), \mathrm{HOAc}(1.5 \mathrm{~mL}, 26.2 \mathrm{mmol})$ and zinc $(900 \mathrm{mg}, 13.8 \mathrm{mmol})$ in EtOAc $(15 \mathrm{~mL})$ was stirred at room temperature for $12 \mathrm{~h}$. The crude reaction mixture was then filtered, evaporated and purified on a flash silica gel column eluted with $n$-hexane-EtOAc (1:1) to afford the corresponding diol 6 (27 $\mathrm{mg}, 89 \%)$ showing the identical proton NMR data and similar specific rotation, $[\alpha]^{20}{ }_{\mathrm{D}}-2.0\left(c 0.50, \mathrm{CHCl}_{3}\right)$, with 6 .

\subsection{Preparation of (S)- and (R)-MTPA Esters of 6}

Two samples of diacardiol B (6; $1.1 \mathrm{mg}, 3.2 \mu \mathrm{mol}$ and $0.9 \mathrm{mg}, 2.6 \mu \mathrm{mol})$ were mixed with $S$-(+)- or $R$-(-)-MTPA-Cl $(15 \mu \mathrm{L}, 80.1 \mu \mathrm{mol})$, respectively, in freshly distilled dry pyridine $(500 \mu \mathrm{L})$ and then stirred under $\mathrm{N}_{2}$ atmosphere at room temperature for $18 \mathrm{~h}$, and the solvent was then removed in vacuo. The products were purified by using a minicolumn chromatography packed with silica gel (200 mesh; petroleum ether/EtOAc, 1:1, v/v) to afford $S$-(+)- and $R$-(-)-MTPA esters 6a $(0.7 \mathrm{mg}, 78 \%)$ and $\mathbf{6 b}(0.8 \mathrm{mg}, 73 \%)$, respectively. The anisotropic analysis was done by acquiring the interfered resonances for ${ }^{1} \mathrm{H} \mathrm{NMR}\left(\mathrm{CDCl}_{3}, 500 \mathrm{MHz}\right)$ of $6 \mathrm{a}: \delta 5.406(1 \mathrm{H}, \mathrm{m}, \mathrm{H}-3), 3.598(3 \mathrm{H}, \mathrm{s}, \mathrm{COOMe}), 2.866$ $(1 \mathrm{H}, \mathrm{m}, \mathrm{H}-2), 1.902$ (1H, m, H-4a), $1.975(1 \mathrm{H}, \mathrm{m}, \mathrm{H}-4 \mathrm{~b}), 1.138(3 \mathrm{H}, \mathrm{d}, J=6.1 \mathrm{~Hz}, \mathrm{H}-15)$, and $1.157(3 \mathrm{H}$, $\mathrm{s}, \mathrm{H}-16)$; and the interfered resonances for ${ }^{1} \mathrm{H} \mathrm{NMR}\left(\mathrm{CDCl}_{3}, 500 \mathrm{MHz}\right)$ of $\mathbf{6 b}: \delta 5.394(1 \mathrm{H}, \mathrm{m}, \mathrm{H}-3)$, 3.651 (3H, s, COOMe), 2.875 (1H, m, H-2), 1.894 (1H, m, H-4a), 1.933 (1H, m, H-4b), 1.190 (3H, d, $J=6.1 \mathrm{~Hz}, \mathrm{H}-15)$, and $1.078(3 \mathrm{H}, \mathrm{s}, \mathrm{H}-16)$.

\subsection{Antimalarial Assay}

Antimalarial activities were determined against chloroquine sensitive (D6, Sierra Leone) and resistant (W2, Indo China) strains of Plasmodium falciparum in vitro by measuring plasmodial LDH activity. Each testing group dissolved in DMSO with a concentration of $2 \mathrm{mg} / \mathrm{mL}$. A $200-\mu \mathrm{L}$ suspension of $P$. falciparum culture ( $2 \%$ parasitemia and 2\% hematocrit in RPMI 1640 medium supplemented with $10 \%$ human serum and $60 \mu \mathrm{g} / \mathrm{mL}$ amikacin) was added to each well, containing $10 \mu \mathrm{L}$ of serially diluted samples, of a 96-well plate. The plate was flushed with a gas mixture of $90 \% \mathrm{~N}_{2}, 5 \% \mathrm{O}_{2}$ and $5 \% \mathrm{CO}_{2}$ and incubated at $37{ }^{\circ} \mathrm{C}$ for $72 \mathrm{~h}$ in a modular incubation chamber. Plasmodial LDH activity was determined by using Malstat reagent. Briefly, $20 \mu \mathrm{L}$ of the incubation mixture were mixed with $100 \mu \mathrm{L}$ of the Malstat reagent and incubated for $30 \mathrm{~min}$. Twenty microliters of a 1:1 mixture of NBT/PES were then added, and the plate was further incubated in dark environment for $1 \mathrm{~h}$. The test was ended by adding 
$100 \mu \mathrm{L}$ of a $5 \%$ acetic acid solution. The plate was monitored at $650 \mathrm{~nm}$. Artemisinin was used as the control drug.

\subsection{MTT Cytotoxicity Assay}

Briefly, human cancer cells in the exponential growth phase were harvested and then seeded into a flat-bottomed 96-well plate, and each well contained $2.0 \times 10^{3}$ cells in $100 \mu \mathrm{L}$ of solution. After incubation for $12 \mathrm{~h}$ in a $5 \%$ humidified $\mathrm{CO}_{2}$ incubator at $37^{\circ} \mathrm{C}$, the compound for testing was added (in triplicate experiments) at six different concentrations. After $72 \mathrm{~h}$, incubating at $37{ }^{\circ} \mathrm{C}, 20 \mu \mathrm{L}$ of MTT were added to each well, and the plate was incubated again at $37{ }^{\circ} \mathrm{C}$ for $3 \mathrm{~h}$. Absorption was then measured by using a SpectraMAX 340 reader (Molecular Devices, Sunnyvale, CA, USA) at $550 \mathrm{~nm}$, with a reference filter at $690 \mathrm{~nm}$, and $\mathrm{IC}_{50}$ values were calculated on the basis of the percentage of inhibition using the linear regression method.

\subsection{Computational Calculation}

The MMFF (Merck molecular force field) minimized structures of Compounds 1-5 were used for the DFT calculations. DFT calculations were performed by applying the PCM solvation models with the dielectric constant representing acetonitrile by using the Gaussian 09 program (Revision A.1, Gaussian, Inc., Wallingford, CT, USA, 2009). Low energy conformations were optimized by using the B3LYP/6-31G(d,p) or MPWLPW91/6-31G(d,p) methods applying the PCM solvation model, and the frequency calculations were performed at the same theoretical levels to verify the true located energy minimal and to generate sets of thermodynamic data at standard condition. The optimized geometries were used for TDDFT calculations at the B3LYP/6-31G(d,p) level applying the same solvation model. The generated excitation energies and rotational strengths were Boltzmann averaged and then fitted to Gaussian functions to generate computed ECD spectra normalized and overlaid with the experimental spectra for comparison [28,29]. The NMR calculations were performed by using the Gauge-invariant atomic orbital (GIAO) method at the B3LYP/6-31G(d,p) and MPW1PW91/6-31G(d,p) levels, and the calculated chemical shifts for TMS at the corresponding levels were used as references (computational details for Compounds $\mathbf{1}-\mathbf{5}$ are provided in the Supplementary Information).

\section{Conclusions}

The diacarperoxide class was likely generated from the terpene biosynthetic pathway, and the endoperoxyl functional group was probably formed by reacting singlet oxygen with an isoprene unit through a Diels-Alder reaction or intramolecular 1,4-addition from a peroxy nucleophile to an $\alpha, \beta$-unsaturated carbonyl. These availabilities have been demonstrated synthetically [30,31]. The diacarperoxide class provides us potent compounds acting against malaria. The peroxy functional group suggests a potential pharmacophore of these compounds, which inspires further synthetic and biological study. The utilization of diverse computational approaches proved an efficient and reliable way to solve stereochemistry issues related to natural products. 


\section{Acknowledgments}

This research was supported by the National Natural Science Fund for Distinguished Young Scholars of China (81225023), the National Natural Science Fund of China (Nos. 81072573, 81302691, 81172978 and 41106127), the Innovation Program of Shanghai municipal Education Commission (No. 14YZ037) and partially supported by the Shanghai Subject Chief Scientist (12XD1400200) and National High Technology Research and Development Program of China (863 Projects, Nos. 2011AA09070107 and 2013AA092902). We are also grateful for the financial support from the National Institutes of Health (Grant No. RO1 AT007318) and Kraft Foods Inc., Deerfield, IL, USA. We thank Shabana Khan for antimalarial assay assistance. We also acknowledged the supercomputing resources provided by the Mississippi Center for Supercomputing Research (MCSR).

\section{Author Contributions}

Fan Yang and Yike Zou contributed to the structural determination and manuscript writing. Yike Zou also performed the chemical computation for compounds 1-5. Ru-Ping Wang conducted the isolation and chemical degradation work for the new compounds. Mark T. Hamann, Hong-Jun Zhang, Wei-Hua Jiao, and Bing-Nan Han gave the constructive suggestions for the experiments and manuscript writing. Fan Yang, Shao-Jiang Song, and Hou-Wen Lin conceived and designed the research.

\section{Conflicts of Interest}

The authors declare no conflict of interest.

\section{References and Notes}

1. Malaria. Available online: http://www.unicef.org/health/index_malaria.html (accessed on 24 September 2013).

2. Klayman, D.L. Qinghaosu (Artemisnin)—An antimalarial drug from China. Science 1985, 228, 1049-1055.

3. Posner, G.H.; Oh, C.H. Regiospecifically oxygen-18 labeled 1,2,4-trioxane: A simple chemical model system to probe the mechanism(s) for the antimalarial activity of artemisinin (qinghaosu). J. Am. Chem. Soc. 1992, 114, 8328-8329.

4. Mayer, A.M.S.; Rodriguez, A.D.; Berlinck, R.G.S.; Hamann, M.T. Marine pharmacology in 2005-6: Marine compounds with anthelmintic, antibacterial, anticoagulant, antifungal, anti-inflammatory, antimalarial, antiprotozoal, antituberculosis, and antiviral activities; affecting the cardiovascular, immune and nervous systems, and other miscellaneous mechanisms of action. Biochim. Biophys. Acta 2009, 1790, 283-308.

5. Kashman, Y.; Rotem, M. Muqubilin, a new C24-isoprenoid from a marine sponge. Tetrahedron Lett. 1979, 20, 1707-1708.

6. Albericci, M.; Collart-Lempereur, M.; Braekman, J.C.; Dalcze, D.; Tursch, B.; Declercq, J.P.; Germain, G.; van Meerssche, M. Chemical studies of marine invertebrates. XLI. Sigmosceptrellin-A methyl ester a nor-sesterterpenoid peroxide from the sponge Sigmosceptrella laevis. Tetrahedron Lett. 1979, 20, 2687-2690. 
7. Scherf, T.; Hiller, R.; Naider, F.; Levitt, M.; Anglister, J. Induced peptide conformations in different antibody complexes: Molecular modeling of the three-dimensional structure of peptide-antibody complexes using NMR-derived distance restraints. J. Biochem. 1992, 31, 6884-6897.

8. Ishikita, H.; Warshel, A. Predicting drug-resistant mutations of HIV protease. Angew. Chem. Int. Ed. 2008, 120, 709-712.

9. Wakai, A.; Fukasawa, H.; Yang, C.; Mori, T.; Inoue, Y. Theoretical and experimental investigations of circular dichroism and absolute configuration determination of chiral anthracene photodimers. J. Am. Chem. Soc. 2012, 134, 4990-4997.

10. Chao, C.-H.; Chou, K.-J.; Wang, G.-H.; Wu, Y.-C.; Wang, L.-H.; Chen, J.-P.; Sheu, J.-H.; Sung, P.-J. Norterpenoids and related peroxides from the Formosan marine sponge Negombata corticata. J. Nat. Prod. 2010, 73, 1538-1543.

11. Ibrahim, S.R.M.; Ebel, R.; Wray, V.; Müller, W.E.G.; Edrada-Ebel, R.; Proksch, P. Diacarperoxides, norterpene cyclic peroxides from the sponge Diacarnus megaspinorhabdosa. J. Nat. Prod. 2008, 71, 1358-1364.

12. Rubio, B.K.; Tenney, K.; Ang, K.-H.; Abdulla, M.; Arkin, M.; McKerrow, J.H.; Crews, P. The marine sponge Diacarnus bismarckensis as a source of peroxiterpene inhibitors of Trypanosoma brucei, the causative agent of sleeping sickness. J. Nat. Prod. 2009, 72, 218-222.

13. Youssef, D.T.A.; Yoshida, W.Y.; Kelly, M.; Scheuer, P.J. Cytotoxic cyclic norterpene peroxides from a Red Sea sponge Diacarnus erythraenus. J. Nat. Prod. 2001, 64, 1332-1335.

14. Capon, R.J.; Macleod, J.K. Structural and stereochemical studies on marine norterpene cyclic peroxides. Tetrahedron 1985, 41, 3391-3404.

15. El Sayed, K.A.; Hamann, M.T.; Hashish, N.E.; Shier, W.T.; Kelly, M.; Khan, A.A. Antimalarial, antiviral, and antitoxoplasmosis norsesterterpene peroxide acids from the Red Sea sponge Diacarnus erythraeanus. J. Nat. Prod. 2001, 64, 522-524.

16. Capon, R.J.; MacLeod, J.K.; Willis, A.C. Trunculins A and B, norsesterterpene cyclic peroxides from a marine sponge, Latrunculia brevis. J. Org. Chem. 1987, 52, 339-342.

17. He, H.Y.; Faulkner, D.J.; Lu, H.S.M.; Clardy, J. Norsesterterpene peroxides from the sponge Latrunculia sp. J. Org. Chem. 1991, 56, 2112-2115.

18. D’Ambrosio, M.; Guerriero, A.; Deharo, E.; Debitus, C.; Munoz, V.; Pietra, F. New types of potentially antimalarial agents: Epidioxy-substituted norditerpene and norsesterpenes from the marine sponge Diacarnus levii. Helv. Chim. Acta 1998, 81, 1285-1292.

19. Capon, R.J.; Rochfort, S.J.; Ovenden, S.P.B.; Metzger, R.P. Mycaperoxides F and G and a related norterpene ketone from Southern Australian marine sponges, Mycale Species. J. Nat. Prod. 1998, $61,525-528$.

20. Karplus, M. Vicinal proton coupling in nuclear magnetic resonance. J. Am. Chem. Soc. 1963, 85, 2870-2871.

21. Side chain was replaced with simplified substitutions (detailed in Supplementary Information).

22. Lodewyk, M.W.; Siebert, M.R.; Tantillo, D.J. Computational prediction of ${ }^{1} \mathrm{H}$ and ${ }^{13} \mathrm{C}$ chemical shifts: A useful tool for natural product, mechanistic, and synthetic organic chemistry. Chem. Rev. 2012, 112, 1839-1862. 
23. Phuwapraisirisan, P.; Matsunaga, S.; Fusetani, N.; Chaitanawisuti, N.; Kritsanapuntu, S.; Menasveta, P. Mycaperoxide $\mathrm{H}$, a new cytotoxic norsesterterpene peroxide from a Thai marine sponge Mycale sp. J. Nat. Prod. 2003, 66, 289-291.

24. Sperry, S.; Valeriote, F.A.; Corbett, T.H.; Crews, P. Isolation and cytotoxic evaluation of marine sponge-derived norterpene peroxides. J. Nat. Prod. 1998, 61, 241-247.

25. Ovenden, S.P.B.; Capon, R.J. Nuapapuin A and sigmosceptrellins D and E: New norterpene cyclic peroxides from a Southern Australian marine sponge, Sigmosceptrella sp. J. Nat. Prod. 1999, 62, 214-218.

26. Yu, H.-B.; Liu, X.-F.; Xu, Y.; Gan, J.-H.; Jiao, W.-H.; Shen, Y.; Lin, H.-W. Woodylides A-C, New cytotoxic linear polyketides from the South China Sea sponge Plakortis simplex. Mar. Drugs 2012, 10, 1027-1036.

27. Ohtani, I.; Kusumi, T.; Kashman, Y.; Kakisawa, H. High-field FT NMR application of Mosher's method. The absolute configurations of marine terpenoids. J. Am. Chem. Soc. 1991, 113, 4092-4096.

28. Zou, Y.; Hamann, M.T. Atkamine: A new pyrroloiminoquinone scaffold from the cold water Aleutian Islands Latrunculia sponge. Org. Lett. 2013, 15, 1516-1519.

29. Grkovic, T.; Ding, Y.; Li, X.-C.; Webb, V.L.; Ferreira, D.; Copp, B.R. Enantiomeric discorhabdin alkaloids and establishment of their absolute configurations using theoretical calculations of electronic circular dichroism spectra. J. Org. Chem. 2008, 73, 9133-9136.

30. Silva, E.M.P.; Pye, R.J.; Brown, G.D.; Harwood, L.M. Towards the total synthesis of mycaperoxide B: Probing biosynthetic rationale. Eur. J. Org. Chem. 2012, 6, 1209-1216.

31. Snider, B.B.; Shi, Z. Total synthesis of (.+-.)-chondrillin, (.+-.)-plakorin, and related peroxy ketals. Development of a general route to 3,6-dihydro-1,2-dioxin-3-ols. J. Am. Chem. Soc. 1992, 114, 1790-1800.

(C) 2014 by the authors; licensee MDPI, Basel, Switzerland. This article is an open access article distributed under the terms and conditions of the Creative Commons Attribution license (http://creativecommons.org/licenses/by/3.0/). 